\title{
The anthelmintic agent oxfendazole inhibits cell growth in non-small cell lung cancer by suppressing c-Src activation
}

\author{
DAFU XU ${ }^{1,2^{*}}$, WENZE TIAN $^{2^{*}}$, CHAO JIANG $^{3}$, ZIMING HUANG $^{4}$ and SHIYING ZHENG ${ }^{1}$ \\ ${ }^{1}$ Department of Thoracic Surgery, The First Affiliated Hospital of Soochow University, Suzhou, Jiangsu 215006; \\ Departments of ${ }^{2}$ Thoracic Surgery, ${ }^{3}$ Oncology and ${ }^{4}$ Emergency Surgery, Huai'an First People's Hospital, \\ The Affiliated Huai'an No. 1 People's Hospital of Nanjing Medical University, Huai'an, Jiangsu 223300, P.R. China
}

Received May 19, 2018; Accepted December 4, 2018

DOI: $10.3892 / \mathrm{mmr} .2019 .9897$

\begin{abstract}
The c-Src protein family of tyrosine kinases are important in the tumorigenesis of many types of tumors, and may be a potential target for antitumor drug discovery. In the present study, immunoblotting was performed to analyze protein expression, CCK-8 assay was carried out to assess cell viability and cell cycle was analyzed using a flow cytometer. The anthelmintic agent oxfendazole was observed to be a novel c-Src inhibitor that blocked the activation of c-Src. Oxfendazole also suppressed the cell growth of non-small cell lung cancer (NSCLC) cells, and overexpression of c-Src decreased the cytotoxicity of oxfendazole against NSCLC cells. In addition, oxfendazole induced cell cycle arrest at the $G_{0} / G_{1}$ phase, and downregulated the protein levels of Cyclin-dependent kinase (CDK)-4, CDK6, retinoblastoma protein and E2 transcription factor 1, and upregulated the expression levels of p53 and p21 in NSCLC cells. Furthermore, oxfendazole enhanced the cytotoxicity of cisplatin against NSCLC cells. These results demonstrated that oxfendazole exerted its antitumor activity by suppressing c-Src signaling, and it was also indicated that the anthelmintic agent oxfendazole may be effective for anti-NSCLC therapy in the clinic as a single agent or in combination with other antitumor drugs.
\end{abstract}

Correspondence to: Professor Shiying Zheng, Department of Thoracic Surgery, The First Affiliated Hospital of Soochow University, Building 33, 296 The Shizi Street, Suzhou, Jiangsu 215006, P.R. China

E-mail: shiying_zheng@hotmail.com

Dr Ziming Huang, Department of Emergency Surgery, Huai'an First People's Hospital, The Affiliated Huai'an No. 1 People's Hospital of Nanjing Medical University, Building 17, 1 The Yellow River West Road, Huai'an, Jiangsu 223300, P.R. China

E-mail: ziming_huang2018@hotmail.com

${ }^{*}$ Contributed equally

Key words: oxfendazole, non-small cell lung cancer, cell growth, $\mathrm{c}-\mathrm{Src}$, cisplatin

\section{Introduction}

Non-small cell lung cancer (NSCLC) is one of the most common malignancies, accounting for $85 \%$ of all lung cancer cases, and its treatment continues to be severe challenge in the clinic (1). Although significant progress has been made in regard to drug development, there are still few drugs that have long-term benefits in the treatment of NSCLC (2-4). Therefore, there is an urgent demand to identify novel targets and drugs to improve systemic therapy for patients with NSCLC.

The c-Src proto-oncogene belongs to the Src family of protein tyrosine kinases, which include c-Src, Fyn, Lyn, Lck, Yes, Blk and Hck (5). c-Src regulates signals from multiple cell surface molecules, including growth factors, $G$ protein-coupled receptors and integrins (6). It has been reported previously that levels of c-Src protein were elevated or kinase activity was overactivated in many types of tumors, including $\operatorname{NSCLC}(7,8)$. In tumor cells, the activation of c-Src mediated cell growth, cell proliferation, cell survival and cell invasion (9). Previous studies have reported that c-Src was activated in NSCLC cells and primary tumor tissues, and its inhibition led to decreased cell growth and cell cycle arrest $(10,11)$.

In the present study, oxfendazole potently suppressed the activation of c-Src in NSCLC cells, and inhibited NSCLC cell survival. In addition, overexpression of c-Src decreased the effects of oxfendazole on NSCLC cells. Further studies revealed that oxfendazole induced cell cycle arrest at the $G_{0} / G_{1}$ phase, and downregulated Cyclin-dependent kinase (CDK) signaling in NSCLC cells, including CDK4, CDK6, retinoblastoma protein (p-Rb) and E2 transcription factor 1 (E2F1) inhibition, and the upregulation of p53 and p21. In addition, oxfendazole enhanced the cytotoxicity of cisplatin against NSCLC cells by reducing c-Src activation.

\section{Materials and methods}

Cells, culture and chemicals. The NSCLC cell lines A549, H460, H1299, H1650 and H1975 were purchased from American Type Culture Collection (Manassas, VA, USA). All NSCLC cell lines were maintained in RPMI-1640 medium with $10 \%$ fetal bovine serum (Gibco; Thermo Fisher Scientific, Inc., Waltham, MA, USA), $100 \mathrm{U} / \mathrm{ml}$ of streptomycin and $100 \mu \mathrm{g} / \mathrm{ml}$ of penicillin. Oxfendazole was purchased from 
Selleck Chemicals (Houston, TX, USA). Cisplatin was purchased from Sigma-Aldrich (Merck KGaA, Darmstadt, Germany).

Epidermal growth factor (EGF) stimulation. A549 and H1299 cells $\left(1 \times 10^{6}\right.$ cells/well) were seeded in 6 -well plates overnight. Then, the cells were starved overnight in serum-free medium. Subsequently, starved A549 and H1299 cells were incubated with 0,10 or $20 \mu \mathrm{M}$ of OFD for $6 \mathrm{~h}$ at $37^{\circ} \mathrm{C}$, then stimulated with $10 \mathrm{ng} / \mathrm{ml}$ EGF (P5552; Beyotime Institute of Biotechnology, Haimen, China) for $20 \mathrm{~min}$ at $37^{\circ} \mathrm{C}$.

Immunoblotting. Immunoblotting was conducted as previously described $(12,13)$. Briefly, cells $\left(1 \times 10^{6}\right.$ cells/well) were lysed by RIPA lysis (P0013B; Beyotime Institute of Biotechnology), and whole cell lysates were extracted. Then, proteins were determined by BCA method (BCA kit, P0011; Beyotime Institute of Biotechnology) and $30 \mu \mathrm{g}$ of total proteins were subjected to SDS-PAGE separation by using $10 \%$ or $12 \%$ acrylamide gel, and the proteins were transferred onto $0.2 \mu \mathrm{m}$ polyvinylidene difluoride (PVDF) membrane (1620177; Bio-Rad Laboratories, Inc., Hercules, CA, USA), followed by immunoblotting with specific antibodies. The primary antibodies phosphorylated (p)-c-Src (Tyr416) (6943; 1:1,000), c-Src (2109; 1:1,000), CDK4 (12790; 1:1,000), CDK6 (13331; 1:1,000), p-Rb (Ser807/811) (8516; 1:1,000), E2F1 (3742; 1:1,000), p53 (2527; 1:1,000) and p21 $(2947 ; 1: 1,000)$ were purchased from Cell Signaling Technology, Inc. (Danvers, MA, USA). Anti-GAPDH antibody (AM1020A; 1:5.000) was purchased from Abgent Biotech Co., Ltd. (Suzhou, China). Anti-mouse (A0216; 1:1,000) and anti-rabbit (A0208; 1:1,000) immunoglobulin G (IgG) horseradish peroxidase-conjugated antibodies were purchased from Beyotime Institute of Biotechnology (Haimen, Nantong, China). All immunoblotting signals were further assessed by using ECL (BeyoECL Plus kit, P0018M; Beyotime Institute of Biotechnology) and analyzed with Quality One software (version number: 4.0.1; Bio-Rad Laboratories, Inc.).

Cell growth and viability. Viable cells $(8,000$ cells/well) were analyzed by Cell Counting Kit-8 (CCK-8; BioTools, Inc., Jupiter, FL, USA) assay according to the manufacturer's instruction, as described previously (14). To assess the effect of OFD on the survival rates of different NSCLC cell lines, 5 NSCLC cell lines were treated with $0,5,10$ or $20 \mu \mathrm{M}$ of OFD for $24 \mathrm{~h}$ at $37^{\circ} \mathrm{C}$, or cells were treated by $5 \mu \mathrm{M}$ OFD for $0,24,48$ or $72 \mathrm{~h}$ at $37^{\circ} \mathrm{C}$, followed by a CCK-8 assay. For the transfected cells, A549 or H1299 cells were treated with 0, 2.5, 5 or $10 \mu \mathrm{M}$ of OFD for $24 \mathrm{~h}$ at $37^{\circ} \mathrm{C}$. In addition, A549 and $\mathrm{H} 1299$ cells were treated with $5 \mu \mathrm{M}$ cisplatin for $24 \mathrm{~h}$ at $37^{\circ} \mathrm{C}$ in the presence or absence of $10 \mu \mathrm{M}$ OFD, and then the cells were assessed by a CCK- 8 assay.

Plasmids construction and gene transfection. The human c-Src gene was generated and cloned into the pcDNA3.1 vector as previously described $(15,16)$. The primers for c-Src amplification were as follows: Forward, 5'-ATGGGTAGC AACAAGAGCAAGC-3' and reverse, 5'-CTAGAGGTTCTC CCCGGGCTGGTA-3'. A549 or H1299 cells were transfected with $1 \mu \mathrm{g} / \mu 1$ empty vector (pcDNA3.1 vector) or $1 \mu \mathrm{g} / \mu 1 \mathrm{c}-\mathrm{Src}$ plasmids for $24 \mathrm{~h}$ by Lipofectamine ${ }^{\circledR} 2000^{\mathrm{TM}}$ (Invitrogen;
Thermo Fisher Scientific, Inc.) according to the manufacturer's instructions.

Cell cycle analysis. Cell cycle analysis was performed as previously described (17). A549 and H1299 cells $\left(1 \times 10^{6}\right.$ cells/well) were treated with 0,5 or $10 \mu \mathrm{M}$ of oxfendazole for $24 \mathrm{~h}$ at $37^{\circ} \mathrm{C}$ prior to cell cycle analysis. Then, cells were fixed with $70 \%$ cold ethanol overnight at $-20^{\circ} \mathrm{C}$ and washed with cold PBS, followed by being resuspended in $100 \mu 1$ PBS containing $100 \mu \mathrm{g} / \mathrm{ml}$ RnaseA (Beijing Solarbio Science \& Technology, Co., Ltd., Beijing, China) for $30 \mathrm{~min}$ at $37^{\circ} \mathrm{C}$. Cells were then washed with cold PBS and incubated with propidium iodide (PI) for $5 \mathrm{~min}$ at room temperature by using the Cell Cycle Detection kit (C1052; Beyotime Institute of Biotechnology). Cell cycle distribution was analyzed on a flow cytometer (Attune ${ }^{\circledR}$ NxT; Thermo Fisher Scientific, Inc.) and the data was analyzed by FlowJo 7.6.1 (FlowJo LLC, Ashland, OR, USA).

Statistical analysis. Statistical analysis was performed using Statistical Package for Social Sciences 13.0 for Windows (SPSS, Inc., Chicago, IL, USA). The results were presented as the mean \pm standard deviation. One-way analysis of variance with Bonferroni post hoc tests were used to determine significance. $\mathrm{P}<0.05$ was considered to indicate a statistically significant difference.

\section{Results}

Oxfendazole inhibits c-Src activation in NSCLC cells. To evaluate the effects of oxfendazole on c-Src activation in NSCLC cells, a panel of NSCLC cell lines were treated with oxfendazole for $24 \mathrm{~h}$, followed by immunoblotting against p-c-Src (Tyr416) and c-Src. As shown in Fig. 1A and B, c-Src was activated in all five NSCLC cell lines, and oxfendazole markedly inhibited the phosphorylation of c-Src. In addition, oxfendazole downregulated the phosphorylation of c-Src in a concentration-dependent manner in A549 and H1299 cells (Fig. 1C). Next, A549 and H1299 cells were starved overnight in serum-free medium followed by oxfendazole treatment and epidermal growth factor (EGF) stimulation. As shown in Fig. 1D, EGF, a key trigger of c-Src signaling, markedly activated c-Src, but this action was suppressed by oxfendazole in a concentration-dependent manner. These results suggested that oxfendazole inhibited the activation of c-Src in NSCLC cells, and that it may be a novel c-Src inhibitor.

Oxfendazole inhibits cell survival in NSCLC cells. It was previously reported that the activation of c-Src promoted the cell survival of tumor cells (9). In the present study, to evaluate the effects of oxfendazole on NSCLC cell survival, a panel of NSCLC cell lines were treated with increased concentrations of oxfendazole for $24 \mathrm{~h}$, followed by a CCK- 8 assay. As shown in Fig. 2A, oxfendazole decreased NSCLC cell viability in a concentration-dependent manner. In addition, oxfendazole also inhibited the cell survival of A549 and H1299 cells in a time-dependent manner (Fig. 2B). Furthermore, when A549 and H1299 cells were transfected with c-Src plasmids, oxfendazole-induced cell death was significantly attenuated (Fig. 2C and D). For example, in A549 cells treated with $10 \mu \mathrm{M}$ of oxfendazole, the fraction of surviving cells was 
A<smiles>COC(=O)Nc1nc2ccc(S(=O)(=O)c3ccccc3)cc2[nH]1</smiles>

B

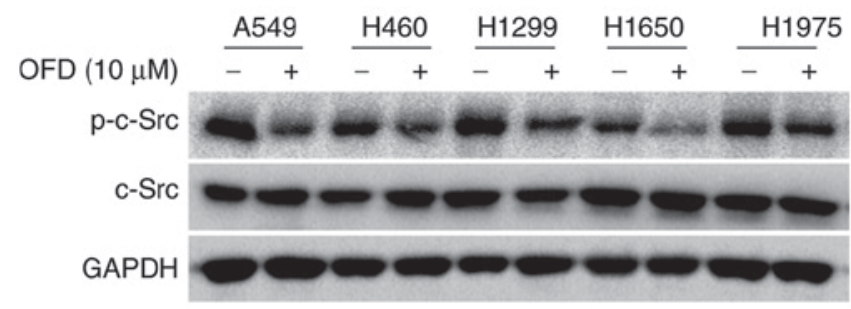

C

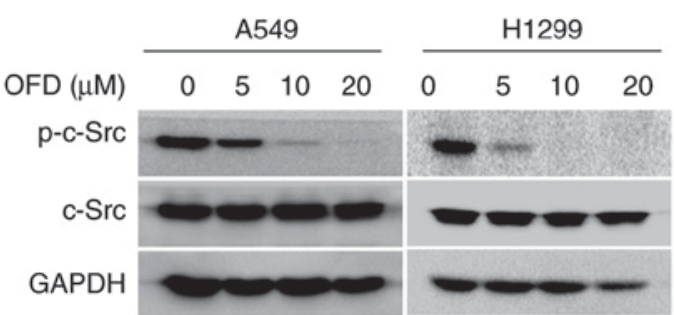

D

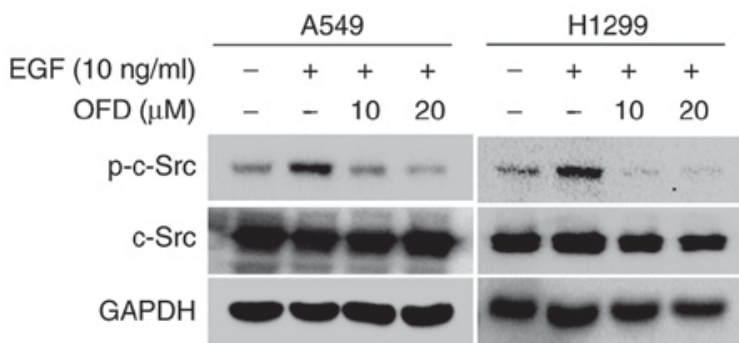

Figure 1. Oxfendazole inhibits c-Src activation in NSCLC cells. (A) The chemical structure of OFD. (B) Five NSCLC cell lines were treated with $10 \mu$ M OFD for $24 \mathrm{~h}$ at $37^{\circ} \mathrm{C}$, and then cells were prepared for immunoblotting against p-c-Src and c-Src. GAPDH was used as an internal control. (C) A549 and H1299 cells were treated with increased concentrations of OFD for $24 \mathrm{~h}$ at $37^{\circ} \mathrm{C}$, followed by immunoblotting against p-c-Src, c-Src and GAPDH. (D) Following starvation overnight in serum-free medium, A549 and H1299 cells were incubated with increased concentrations of OFD for 6 h, then stimulated with EGF (10 ng/ml) for $20 \mathrm{~min}$ at $37^{\circ} \mathrm{C}$. The cells were then prepared for immunoblotting against p-c-Src, c-Src and GAPDH. NSCLC, non-small cell lung cancer; OFD, oxfendazole; p-, phosphorylated; EGF, epidermal growth factor.

A

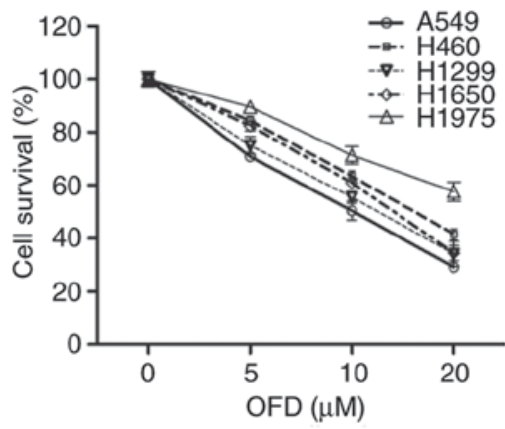

C

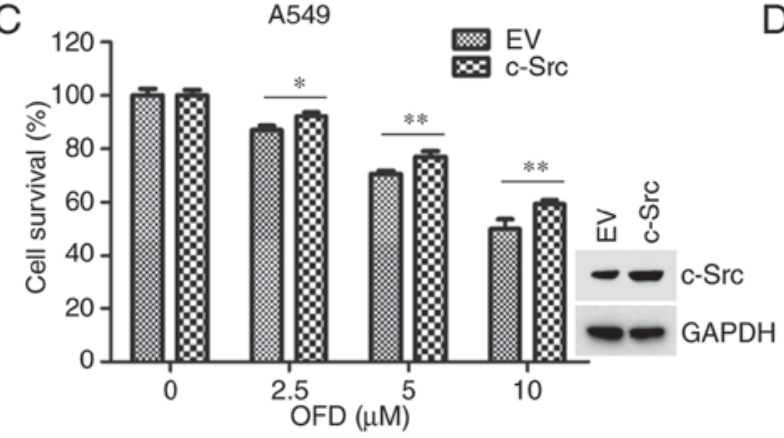

B
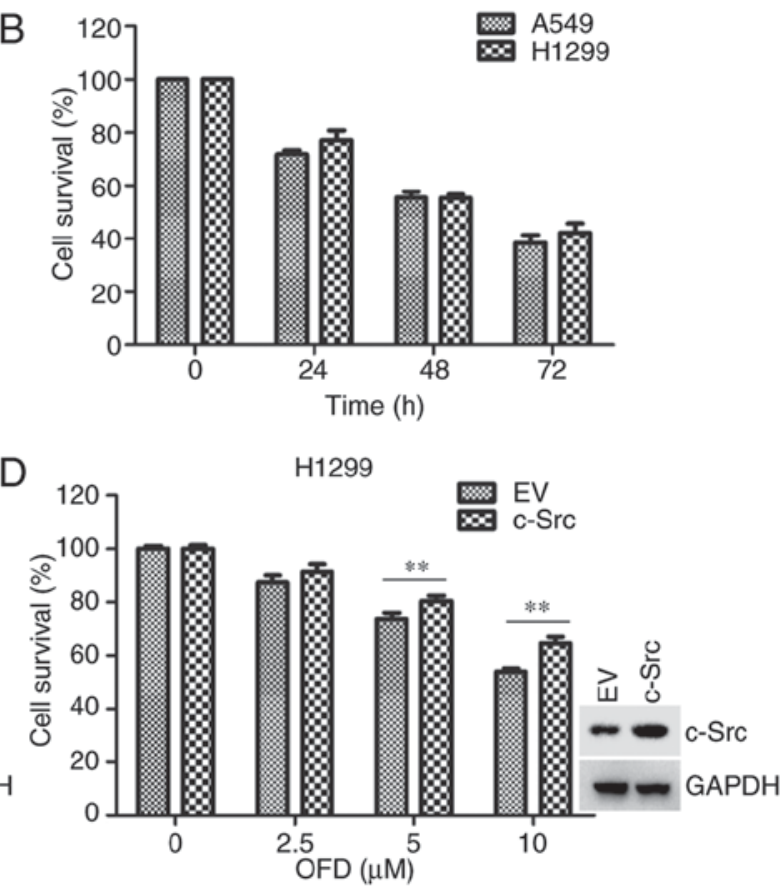

Figure 2. OFD inhibits cell survival in NSCLC cells. (A) The NSCLC cell lines A549, H460, H1299, H1650 and H1975 were treated with the indicated concentrations of OFD for $24 \mathrm{~h}$ at $37^{\circ} \mathrm{C}$, followed by a CCK-8 assay. (B) A549 and $\mathrm{H} 1299$ cells were treated by $5 \mu \mathrm{M}$ OFD for the indicated times at $37^{\circ} \mathrm{C}$, and then cells were prepared for the CCK-8 assay. (C) A549 and (D) H1299 cells were transfected with $1 \mu \mathrm{g} / \mu \mathrm{l} \mathrm{EV} \mathrm{(pcDNA3.1} \mathrm{vector)} \mathrm{or} 1 \mu \mathrm{g} / \mu \mathrm{l}$ c-Src plasmids for $24 \mathrm{~h}$, and then cells were treated with increasing concentrations of OFD for $24 \mathrm{~h}$ at $37^{\circ} \mathrm{C}$, followed by a CCK-8 assay and immunoblotting. ${ }^{*} \mathrm{P}<0.05$ and ${ }^{* *} \mathrm{P}<0.01$, as indicated. EV, empty vector; NSCLC, non-small cell lung cancer; OFD, oxfendazole; CCK, Cell Counting Kit.

increased from $50 \%$ in vector-transfected cells to $60 \%$ in c-Src-transfected cells (Fig. 2C). In H1299 cells treated with $10 \mu \mathrm{M}$ of oxfendazole, the fraction of surviving cells was increased from $55 \%$ in vector-transfected cells to $65 \%$ in c-Src-transfected cells (Fig. 2D). These results indicated that c-Src signaling may be involved in the underlying mechanism of the action of oxfendazole.
Oxfendazole inhibits cell cycle progression and suppresses CDK signaling in NSCLC cells. It has been previously reported that c-Src activation regulated the cell growth and cell cycle of tumor cells $(18,19)$. Therefore, the present study evaluated whether oxfendazole regulated the cell cycle of NSCLC cells. As shown in Fig. 3, flow cytometry revealed that oxfendazole induced cell cycle arrest at the $\mathrm{G}_{0} / \mathrm{G}_{1}$ phase in 


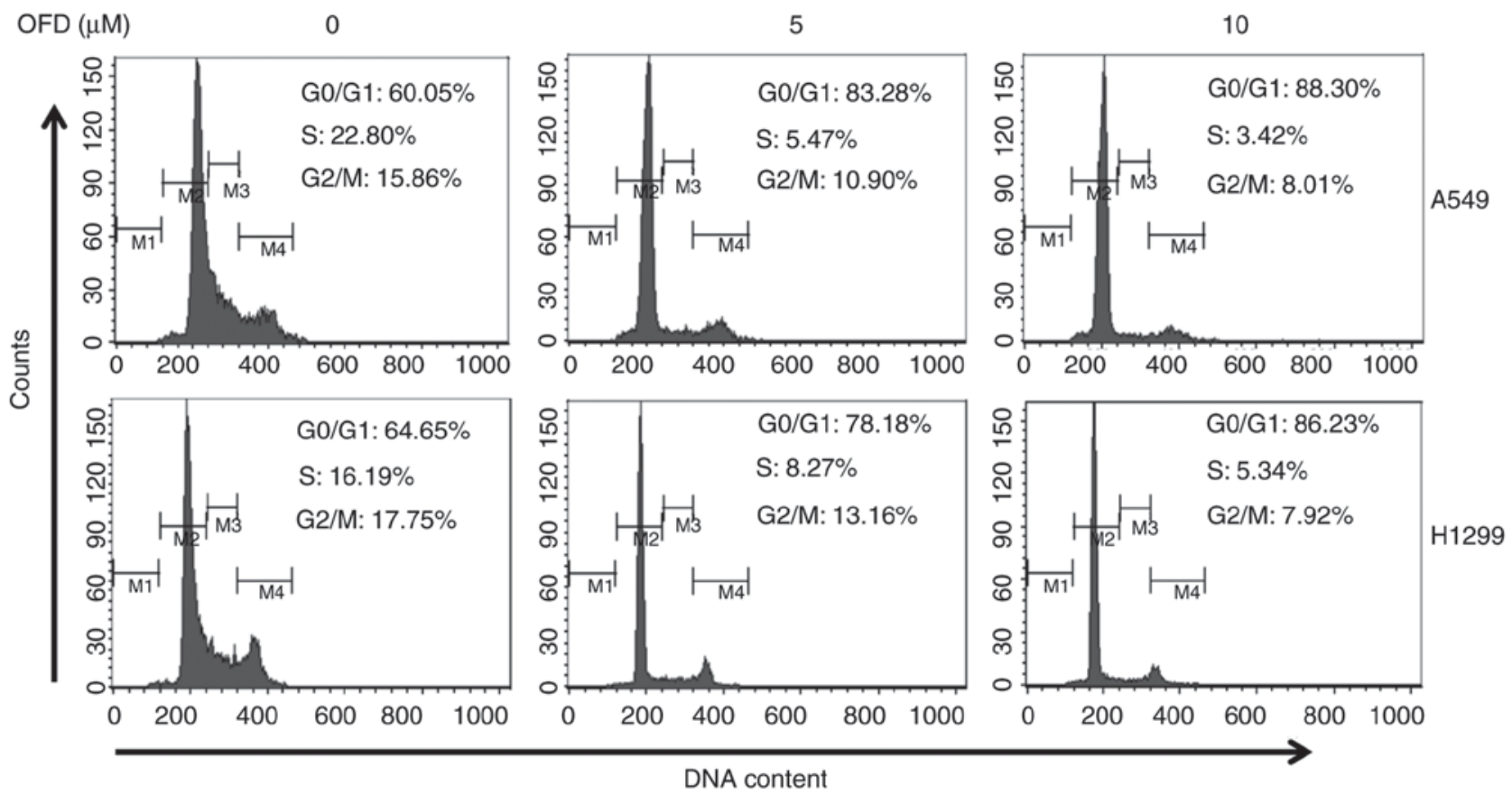

Figure 3. OFD inhibits cell cycle progression in non-small cell lung cancer cells. A549 and H1299 cells were treated with the indicated concentrations of OFD for $24 \mathrm{~h}$ at $37^{\circ} \mathrm{C}$, and then cells were collected for DNase-free RNase treatment, followed by propidium iodide staining and analyzed on a flow cytometer. OFD, oxfendazole.

A549 and H1299 cells. In A549 cells, the fraction of the $\mathrm{G}_{0} / \mathrm{G}_{1}$ cells was increased from $60.05 \%$ in the control to $88.30 \%$ in cells treated with $10 \mu \mathrm{M}$ oxfendazole, coupled with a decrease in the fraction of S phase cells from 22.80 to $3.42 \%$ (Fig. 3; upper panel). In $\mathrm{H} 1299$ cells, the percentage of $\mathrm{G}_{0} / \mathrm{G}_{1}$ cells was increased from 64.65 to $86.23 \%$ following treatment with $10 \mu \mathrm{M}$ oxfendazole, coupled with a decrease in the fraction of S phase cells from 16.91 to $5.34 \%$ (Fig. 3; lower panel).

$\mathrm{D}$-cyclins combine with CDK4/6 to phosphorylate $\mathrm{p}-\mathrm{Rb}$, allowing for the release of E2F transcription factors, which activate G1/S-phase gene expression (20). Thus, the present study next evaluated the effects of oxfendazole on the expression of these proteins. As shown in Fig. 4A and B, oxfendazole downregulated the expression levels of CDK4, CDK6, p-Rb and $\mathrm{E} 2 \mathrm{~F} 1$ in a concentration-dependent manner.

The p53 tumor suppressor protein serves a major role in arresting cell cycle progression (21). To determine whether p53 was associated with oxfendazole cytotoxicity in cell survival, the present study then examined the expression of p53. As shown in Fig. 4C, oxfendazole upregulated p53 expression. The expression of p21 expression was also detected, which is a potent CDK inhibitor and a target of p53 (22). As shown in Fig. 4C, oxfendazole markedly upregulated p21 expression.

These results indicated that oxfendazole inhibited cell cycle progression by suppressing CDK signaling in NSCLC cells, and its activity in survival inhibition in NSCLC cells was observed.

Oxfendazole enhances the cytotoxicity of cisplatin against NSCLC cells. Cisplatin is a common chemotherapeutic drug for NSCLC therapy, but resistance is frequently observed during the process of NSCLC treatment in the clinic (23-25).
It has been reported that overactivation of c-Src could result in drug resistance to NSCLC treatment $(10,26)$; thus, the present study then evaluated whether oxfendazole could enhance the effect of cisplatin in the treatment of NSCLC cells. As shown in Fig. 5A, the CCK-8 assay demonstrated that oxfendazole enhanced the cytotoxicity of cisplatin against A549 and H1299 cells. In addition, the immunoblotting analysis revealed that the combination of oxfendazole and cisplatin could enhance the inhibition of c-Src activation, as well as the upregulation of p53 (Fig. 5B). Therefore, oxfendazole enhanced the cytotoxic activity of cisplatin by suppressing c-Src activation, and oxfendazole could utilized for anti-NSCLC therapy in the clinic in combination with other antitumor drugs, such as cisplatin.

\section{Discussion}

The current strategies being investigated for NSCLC treatment have focused on new targeted therapies against epidermal growth factor receptor, angiogenesis and immune checkpoints. However, these therapies have exhibited limited benefits for patients with NSCLC (27-29). Therefore, novel and effective drugs are urgently required to treat NSCLC, and one possible strategy is to utilize previously discovered drugs that are currently used to treat different diseases (14). In the present study, the anthelmintic agent oxfendazole significantly displayed antitumor activity in NSCLC cells; thus, the effect of oxfendazole in vivo will be tested in future work.

In epithelial cancers, including NSCLC, c-Src and other Src-associated kinases (including Fyn, Yes and Lyn) are overexpressed and activated, and their levels are closely associated with tumor progression (30). As expected, suppressing Src family kinases in these tumors led to the inhibition of cell 

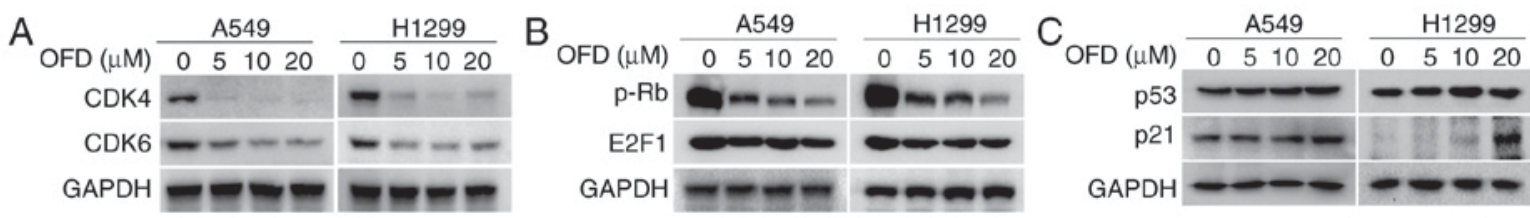

Figure 4. OFD inhibits CDK signaling in non-small cell lung cancer cells. (A) A549 and H1299 cells were treated with the indicated concentrations of OFD for $24 \mathrm{~h}$ at $37^{\circ} \mathrm{C}$, and then cells were prepared for immunoblotting against CDK4, CDK6 and GAPDH. (B) A549 and H1299 cells were treated with the indicated concentrations of OFD for $24 \mathrm{~h}$ at $37^{\circ} \mathrm{C}$, followed by immunoblotting against p-Rb, E2F1 and GAPDH. (C) Following treatment with the indicated concentrations of OFD for $24 \mathrm{~h}$ at $37^{\circ} \mathrm{C}, \mathrm{A} 549$ and $\mathrm{H} 1299$ cells were analyzed by immunoblotting against p53, p21 and GAPDH. OFD, oxfendazole; CDK, Cyclin-dependent kinase; p-Rb, protein retinoblastoma; E2F1, E2 transcription factor 1.
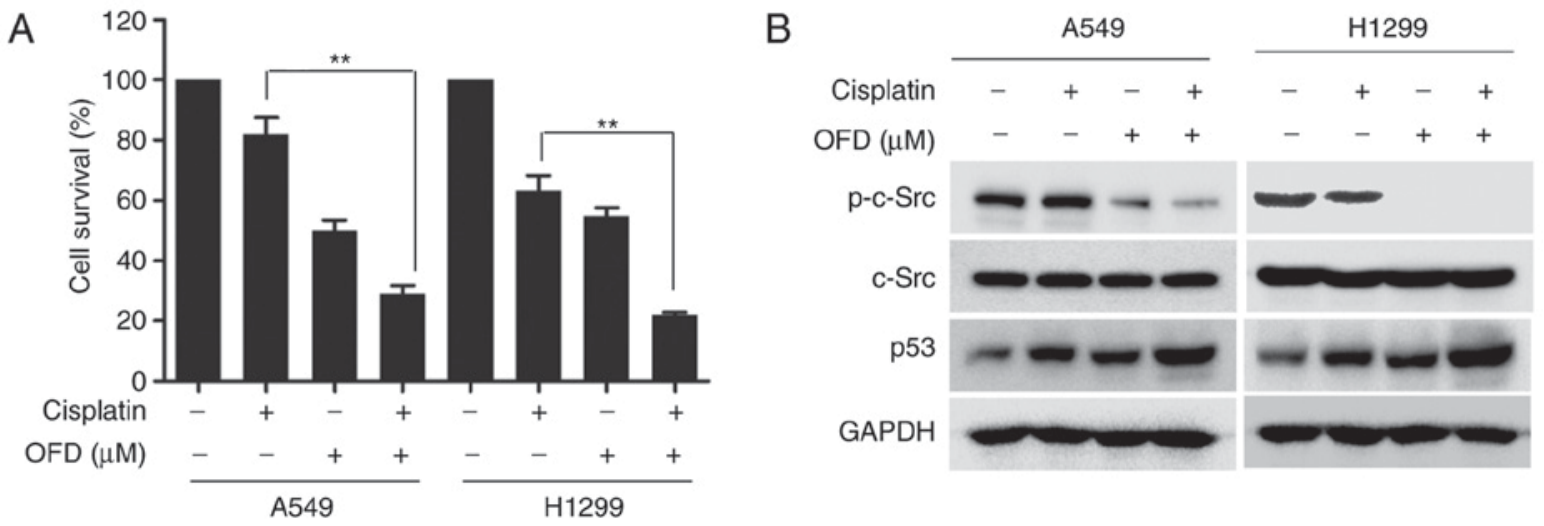

Figure 5. OFD enhances the cytotoxicity of cisplatin against non-small cell lung cancer cells. (A) A549 and H1299 cells were treated with $5 \mu \mathrm{M}$ cisplatin for $24 \mathrm{~h}$ at $37^{\circ} \mathrm{C}$ in the presence or absence of $10 \mu \mathrm{M}$ OFD, and then the cells were assessed by CCK-8 assay. (B) Cells were also prepared for immunoblotting against p53, p-c-Src, c-Src and GAPDH. ${ }^{* *} \mathrm{P}<0.01$, as indicated. OFD, oxfendazole; CCK, Cell Counting Kit; p-, phosphorylated.

growth, and c-Src has been considered to be an ideal drug target for various cancer treatments (31). For example, Dasatinib, a small molecule tyrosine kinase inhibitor, inhibited cell migration and invasion, and induced cell cycle arrest (blocking the G1-S transition) by suppressing c-Src activation in head and neck squamous cell carcinoma and NSCLC cells (9). In the present study, oxfendazole inhibited the activation of c-Src in different NSCLC cell lines, and overexpression of c-Src decreased the cytotoxicity of oxfendazole in A549 and H1299 cells, which suggested that oxfendazole could be used as a novel c-Src inhibitor.

Signaling through c-Src has been reported to be involved in tumor progression, including cell cycle regulation, angiogenesis, cell survival, cell invasion and metastasis (32). Therefore, the present study analyzed the cell cycle of NSCLC cells following treatment with oxfendazole via flow cytometry. The results revealed that oxfendazole induced cell cycle arrest at the $\mathrm{G}_{0} / \mathrm{G}_{1}$ phase in A549 and H1299 cells, and further immunoblotting demonstrated that oxfendazole inhibited CDK signaling, which is the downstream signaling pathway of c-Src.

Cisplatin is a common chemotherapeutic drug in the treatment of lung cancer, but patients frequently develop resistance to it partly due to the overactivation or overexpression of c-Src (10). As described above, oxfendazole inhibited the activation of c-Src, so the present study next investigated whether oxfendazole could enhance the cytotoxicity of cisplatin in NSCLC cells. The results demonstrated that oxfendazole enhanced the cytotoxic activity of cisplatin against NSCLC cells, which suggested that oxfendazole may be effective in
NSCLC therapy in the clinic in combination with other drugs, such as cisplatin.

In conclusion, the present study demonstrated that the anthelmintic agent oxfendazole exerted its antitumor action by suppressing c-Src activation in NSCLC cells. The results suggests that oxfendazole may be effective as a novel type of NSCLC treatment in the clinic in the future.

\section{Acknowledgements}

The authors would like to thank Dr Jerry Xu (Department of Medicine, Soochow University, Suzhou, China) for his discussion and assisting with the design of this project.

\section{Funding}

The present study was supported by the General Project of Science and Technology Development Fund of Nanjing Medical University (grant no. 2013NJMU225).

\section{Availability of data and materials}

All data generated or analyzed during this study are included in this published article.

\section{Authors' contributions}

DX, WT and CJ performed the experiments. DX and SZ wrote and edited the manuscript. $\mathrm{ZH}$ and SZ designed the research project. All authors read and approved the final manuscript. 


\section{Ethics approval and consent to participate}

Not applicable.

\section{Patient consent for publication}

Not applicable.

\section{Competing interests}

All authors declare that they have no competing interests.

\section{References}

1. Ling C, Chen G, Chen G, Zhang Z, Cao B, Han K, Yin J, Chu A, Zhao Y and Mao X: A Deuterated analog of dasatinib disrupts cell cycle progression and displays anti-non-small cell lung cancer activity in vitro and in vivo. Int J Cancer 131: 2411-2419, 2012.

2. Pasquini G and Giaccone G: C-MET inhibitors for advanced non-small cell lung cancer. Expert Opin Investig Drugs 27: 363-375, 2018.

3. Mazzarella L, Guida A and Curigliano G: Cetuximab for treating non-small cell lung cancer. Expert Opin Biol Ther 18: 483-493, 2018.

4. Sun YW, Xu J, Zhou J and Liu WJ: Targeted drugs for systemic therapy of lung cancer with brain metastases. Oncotarget 9 : $5459-5472,2018$

5. Thomas SM and Brugge JS: Cellular functions regulated by Src family kinases. Annu Rev Cell Dev Biol 13: 513-609, 1997.

6. Koppikar P, Choi SH, Egloff AM, Cai Q, Suzuki S, Freilino M, Nozawa H, Thomas SM, Gooding WE, Siegfried JM and Grandis JR: Combined inhibition of c-Src and epidermal growth factor receptor abrogates growth and invasion of head and neck squamous cell carcinoma. Clin Cancer Res 14: 4284-4291, 2008.

7. Nan Y, Du J, Ma L, Jiang H, Jin F and Yang S: Early Candidate biomarkers of non-small cell lung cancer are screened and identified in premalignant lung lesions. Technol Cancer Res Treat 16: 66-74, 2017.

8. Zhang J, Kalyankrishna S, Wislez M, Thilaganathan N, Saigal B, Wei W, Ma L, Wistuba II, Johnson FM and Kurie JM: SRC-family kinases are activated in non-small cell lung cancer and promote the survival of epidermal growth factor receptor-dependent cell lines. Am J Pathol 170 : 366-376, 2007.

9. Johnson FM, Saigal B, Talpaz M and Donato NJ: Dasatinib (BMS-354825) tyrosine kinase inhibitor suppresses invasion and induces cell cycle arrest and apoptosis of head and neck squamous cell carcinoma and non-small cell lung cancer cells. Clin Cancer Res 11: 6924-6932, 2005.

10. Ceppi P, Papotti M, Monica V, Lo Iacono M, Saviozzi S, Pautasso M, Novello S, Mussino S, Bracco E, Volante M and Scagliotti GV: Effects of Src kinase inhibition induced by dasatinib in non-small cell lung cancer cell lines treated with cisplatin. Mol Cancer Ther 8: 3066-3074, 2009.

11. Kiefer PE, Wegmann B, Bacher M, Erbil C, Heidtmann H and Havemann K: Different pattern of expression of cellular oncogenes in human non-small-cell lung cancer cell lines. J Cancer Res Clin Oncol 116: 29-37, 1990.

12. Xu X, Han K, Zhu J, Mao H, Lin X, Zhang Z, Cao B, Zeng Y and Mao X: An inhibitor of cholesterol absorption displays anti-myeloma activity by targeting the JAK2-STAT3 signaling pathway. Oncotarget 7: 75539-75550, 2016.

13. Han K, Xu X, Chen G, Zeng Y, Zhu J, Du X, Zhang Z, Cao B, Liu Z and Mao X: Identification of a promising PI3K inhibitor for the treatment of multiple myeloma through the structural optimization. J Hematol Oncol 7: 9, 2014.

14. Xu X, Wang J, Han K, Li S, Xu F and Yang Y: Antimalarial drug mefloquine inhibits nuclear factor kappa B signaling and induces apoptosis in colorectal cancer cells. Cancer Sci 109: 1220-1229, 2018.
15. Xu X, Han K, Tang X, Zeng Y, Lin X, Zhao Y, Zhang Z, Cao B, Wu D and Mao X: The ring finger protein RNF6 induces leukemia cell proliferation as a direct target of pre-B-cell leukemia homeobox 1. J Biol Chem 291: 9617-9628, 2016.

16. Chen G, Xu X, Tong J, Han K, Zhang Z, Tang J, Li S, Yang C, Li J, Cao B, et al: Ubiquitination of the transcription factor c-MAF is mediated by multiple lysine residues. Int J Biochem Cell Biol 57: 157-166, 2014.

17. Xu X, Zhang J, Han K, Zhang Z, Chen G, Zhang J, Mao X and Cao B: Natural pesticide dihydrorotenone arrests human plasma cancer cells at the G0/G1 phase of the cell cycle. J Biochem Mol Toxicol 28: 232-238, 2014.

18. Kohlmaier A, Fassnacht C, Jin Y, Reuter H, Begum J, Dutta D and Edgar BA: Src kinase function controls progenitor cell pools during regeneration and tumor onset in the Drosophila intestine. Oncogene 34: 2371-2384, 2015.

19. Chan CM, Jing X, Pike LA, Zhou Q, Lim DJ, Sams SB, Lund GS, Sharma V, Haugen BR and Schweppe RE: Targeted inhibition of Src kinase with dasatinib blocks thyroid cancer growth and metastasis. Clin Cancer Res 18: 3580-3591, 2012.

20. Alinari L, Prince CJ, Edwards RB, Towns WH, Mani R, Lehman A, Zhang X, Jarjoura D, Pan L, Kinghorn AD, et al: Dual targeting of the Cyclin/Rb/E2F and mitochondrial pathways in mantle cell lymphoma with the translation inhibitor silvestrol. Clin Cancer Res 18: 4600-4611, 2012.

21. O'Connor PM, Jackman J, Jondle D, Bhatia K, Magrath I and Kohn KW: Role of the p53 tumor suppressor gene in cell cycle arrest and radiosensitivity of Burkitt's lymphoma cell lines. Cancer Res 53: 4776-4780, 1993.

22. Matsuoka S, Edwards MC, Bai C, Parker S, Zhang P, Baldini A, Harper JW and Elledge SJ: p57KIP2, a structurally distinct member of the p21CIP1 Cdk inhibitor family, is a candidate tumor suppressor gene. Genes Dev 9: 650-662, 1995.

23. Sarin N, Engel F, Kalayda GV, Mannewitz M, Cinatl J Jr, Rothweiler F, Michaelis M, Saafan H, Ritter CA, Jaehde U and Frötschl R: Cisplatin resistance in non-small cell lung cancer cells is associated with an abrogation of cisplatin-induced G2/M cell cycle arrest. PLoS One 12: e0181081, 2017.

24. Qin X, Qiu F and Zou Z: TRIM25 is associated with cisplatin resistance in non-small-cell lung carcinoma A549 cell line via downregulation of 14-3-3sigma. Biochem Biophys Res Commun 493: 568-572, 2017.

25. Feng X, Liu H, Zhang Z, Gu Y, Qiu H and He Z: Annexin A2 contributes to cisplatin resistance by activation of JNK-p53 pathway in non-small cell lung cancer cells. J Exp Clin Cancer Res 36: 123, 2017.

26. Ochi N, Takigawa N, Harada D, Yasugi M, Ichihara E, Hotta K, Tabata M, Tanimoto M and Kiura K: Src mediates ERK reactivation in gefitinib resistance in non-small cell lung cancer. Exp Cell Res 322: 168-177, 2014.

27. Remon J, Vilariño N and Reguart N: Immune checkpoint inhibitors in non-small cell lung cancer (NSCLC): Approaches on special subgroups and unresolved burning questions. Cancer Treat Rev 64: 21-29, 2018.

28. Janning $M$ and Loges S: Anti-angiogenics: Their value in lung cancer therapy. Oncol Res Treat 41: 172-180, 2018.

29. Han B, Yang L, Wang X and Yao L: Efficacy of pemetrexed-based regimens in advanced non-small cell lung cancer patients with activating epidermal growth factor receptor mutations after tyrosine kinase inhibitor failure: A systematic review. Onco Targets Ther 11: 2121-2129, 2018.

30. Rho O, Kim DJ, Kiguchi K and Digiovanni J: Growth factor signaling pathways as targets for prevention of epithelial carcinogenesis. Mol Carcinog 50: 264-279, 2011.

31. Elsberger B1, Stewart B, Tatarov O and Edwards J: Is Src a viable target for treating solid tumours? Curr Cancer Drug Targets 10: 683-694, 2010.

32. Gu Z, Fang X, Li C, Chen C, Liang G, Zheng X and Fan Q: Increased PTPRA expression leads to poor prognosis through c-Src activation and G1 phase progression in squamous cell lung cancer. Int J Oncol 51: 489-497, 2017. 